\title{
Occurrence of Fluoride in the Groundwater of Kaltungo Area and Environs, North Eastern Nigeria
}

\author{
Shehu Mukkafa1 ${ }^{*}$, Jackson Makpane Ishaku², Ibrahim Abdulkarim Kwami ${ }^{3}$, \\ Ahmed Buba Seli' ${ }^{4}$ Usman Adamu Abubakar', Abdulwahab Mohammed Bello ${ }^{3}$, \\ Usman Abubakar ${ }^{3}$, Musa Usman Bappa ${ }^{3}$ \\ ${ }^{1}$ Department of Environmental Management and Toxicology, Federal University Dutse, Dutse, Nigeria \\ ${ }^{2}$ Department of Geology, School of Physical Science, Modibbo Adama University of Technology, Yola, Nigeria \\ ${ }^{3}$ Geology Department, Gombe State University, Gombe, Nigeria \\ ${ }^{4}$ Departmentof Civil Engineering, Adamawa State Polytechnic, Yola, Nigeria \\ ${ }^{5}$ Departmentof Chemistry, Gombe State University, Gombe, Nigeria \\ Email: *ababio1011@gmail.com
}

How to cite this paper: Mukkafa, S., Ishaku, J. M., Kwami, I. A., Seli, A. B., Abubakar, U. A., Bello, A. M., Abubakar, U., \& Bappa, M. U. (2019). Occurrence of Fluoride in the Groundwater of Kaltungo Area and Environs, North Eastern Nigeria. Journal of Geoscience and Environment Protection, 7, 167-179.

https://doi.org/10.4236/gep.2019.78012

Received: March 20, 2019

Accepted: August 20, 2019

Published: August 23, 2019

Copyright $\odot 2019$ by author(s) and Scientific Research Publishing Inc. This work is licensed under the Creative Commons Attribution International License (CC BY 4.0).

http://creativecommons.org/licenses/by/4.0/

\begin{abstract}
The aim of the study is to assess the occurrence of fluoride in the groundwater of Kaltungo area and environs. Consumption of high fluoride waters clearly manifests in the majority inhabitant of the area in form of dental fluorosis especially in the majority of the populace. Thirty groundwater samples were collected from hand-dug wells and boreholes using standard method and were analyzed to determine the fluoride level. The results revealed that the Fluoride in the waters ranges from 0.8 to $1.94 \mathrm{mg} / \mathrm{l}$ with a mean value of $1.65 \mathrm{mg} / \mathrm{l}$. No clear variations in fluoride content have been observed in both the borehole samples and those from the hand-dug wells. Ca-Mg- $-\mathrm{HCO}_{3}$ and $\mathrm{Ca}-\mathrm{Mg}-\mathrm{Cl}$ are the two major water types obtained in the area, which have a good association with fluoride. Negative correlation is observed between fluoride and temperature, fluoride and magnesium, fluoride and potassium and poor correlation is observed between fluoride and chloride, fluoride and nitrate, fluoride and phosphates which rules out the possibility of anthropogenic source of the fluoride in the waters. Positive correlation between fluoride and iron, indicates that the presence of fluoride in the water is as a result of dissolution of biotite within the host rock (Basalt).
\end{abstract}

\section{Keywords}

Anthropogenic, Correlation, Fluoride, Kaltungo 


\section{Introduction}

Fluorine often occurs in combined form in minerals like fluoride. Fluoride is a naturally occurring chemical substance present in minor quantities in air, water, soil, plants, animals and humans (Haruna et al., 2014). It is the most electronegative of all chemical elements and is therefore never encountered in nature in the elemental form; however it is highly reactive and represents about $0.06 \%$ to $0.09 \%$ of the earth crust (WHO, 2004). The main source of fluorine in groundwater is basically from mafic minerals which are concentrated in rocks. Fluoride rich minerals which are present in rocks and soils, when in contact with water of high alkalinity are released into groundwater by hydrolysis. However, fluoride is present universally in all waters but higher concentrations are found in groundwater, minerals and rocks. The optimal value of fluoride in drinking water is considered to be around $0.5-1.5 \mathrm{mg} / \mathrm{l}$ (WHO, 2004) and too low $(<0.5 \mathrm{mg} / \mathrm{l})$ or too much $(>1.5 \mathrm{mg} / \mathrm{l})$ which can affect bone and teeth structure. Higher concentration of fluoride also causes respiratory failure, drop in blood pressure and paralysis. Continuous intake of nonfatal dose of fluorides causes permanent inhibition of growth. Lar and Tejan (2008) highlighted the human health effect related to the consumption of fluoride in groundwater particularly in Nigeria. Dibal, et al. (2008) reported the high incidence of dental fluorosis to consumption of high fluoride in groundwater of Langtang area. Dibal and Schoeneich (2009) reported the occurrence of high fluoride in groundwater in several rural communities in some parts of northern Nigeria. The most common symptoms of fluoride effects are dental fluorosis, a condition involving interaction of fluoride with tooth enamel, which involves blackening or staining, weakening and possible eventual loss of teeth. With high exposure to fluoride, skeletal fluorosis can result. This manifests in the earliest stages of osteoclerosis which involves hardening and calcifying of bones and causing stiffness, pain, and irregular bone growth. At its persisting, the condition can result in severe bone deformation. Degree of weathering and the leachable $\mathrm{F}$ in a hard rock terrain is more important in deciding $\mathrm{F}$ content in the water rather than the mere presence of $\mathrm{F}^{-}$-bearing minerals in the bulk rocks/soils (Ramesam \& Rajagopalan, 1985). However, Fluoride-bearing minerals (fluorite, apatite, biotite, hornblende, etc.) present in hard rock terrains (basalts, granites, gneisses, schists, charnockites, khondalites, etc.) and anthropogenic sources (chemical fertilizers, sewage, sludge, etc.) in India are mainly responsible for higher content of $\mathrm{F}$ in groundwater with a combination of higher rate of evaporation and longer interaction of water with aquifer materials under alkaline environment (Shaji et al., 2007; Srinivasamoorthy et al., 2008, 2012; Ramachandran et al., 2012; Reddy et al., 2010; Deepu \& Shaji, 2011; Chidambaram et al., 2013; Manikandan et al., 2014). Also Handa (1975) reported positive correlation between fluoride and silica as well as between fluoride and sodium in groundwater, which indicate a silica-mineral source of fluoride. According to (Abu Rukah \& Alsokhny, 2004; Jacks et al., 2004), the concentration of fluoride in groundwater depends on the geological, chemical and physical characteristics of aquifers (e.g., porosity and acidity of soils, rocks, 
temperature and depth).

Dental fluorosis is a common manifestation in the inhabitants of the study area. This has inspired this study in order to determine the occurrence of fluoride in the groundwater of Kaltungo area and environs.

\section{Description of the Study Area}

Kaltungo area and environs is the study area located in the north eastern part of Nigeria and is defined by Latitudes $9^{\circ} 45^{\prime} 00^{\prime \prime} \mathrm{N}$ and $9^{\circ} 51^{\prime} 00^{\prime \prime} \mathrm{N}$ and Longitudes, $11^{\circ} 15^{\prime} 00^{\prime \prime} \mathrm{E}$ and $11^{\circ} 21^{\prime} 00^{\prime \prime} \mathrm{E}$ and covers an area of about $121 \mathrm{~km}^{2}$. The study area is characterized by tropical continental (Sudan) climate. It is also characterized by two seasons; a rainy season, which starts in April and ends in October and the dry season, which normally spans between November and April. The vegetation of the area is of Sudan Savannah type which covers more than half of northern Nigeria. It is characterized by short grasses with sporadic thorny bushes and scattered trees. The topography of the area is generally hilly with some parts having elevations more than the other surroundings. The elevation ranges from about $450 \mathrm{~m}$ to $850 \mathrm{~m}$ (Figure 1 ). The outcrops generally consist of rocks which are made up of Coarse Porphyritic granite, Biotite granite, Bima sandstones and Tertiary Basalt. Surface drainage systems in the study area comprise numerous streams formed in the direction of the river basin towards the southeast.

\section{Geology of the Study Area}

The study area is underlain by Pre Cambrian Basement Complex rocks and Cretaceous sediments. The basement Complex rocks are represented by Coarse Porphyritic Granite and Biotite Granites, the Cretaceous sediment is represented by Bima Formations and the Tertiary Volcanic Rock is represented by Basalt (Figure 2). Studies indicate that the rocks in the area were subjected to a wide range of tectonic disturbances involving Faulting. The orientation of the fault is mainly trending NE-SW. The continental Bima formation is the basal part of the sedimentary successions in the study area. It lies unconformably on the Precambrian Basement Complex. It ranges in age from Upper Aptian to Lower Albian (Allix et al., 1981). The sediments consist of poorly sorted, angular, highly arkosic pebbly sandstones, granulestones and pebble conglomerates (Zarboski et al., 1997). However, over $50 \%$ of the area is underlain by coarse porphyritic granite intruded by small portion of fine grained biotite granites on the extreme south western part of the map (Figure 2), volcanic rocks are also common. The southern, northern and eastern portion of the study area is underlain by Bima Sandstone with intrusions of basalt to the southern part, which belongs to the Tertiary Volcanic Basalt that intruded into the Benue Trough.

\section{Materials and Method}

A total of 30 groundwater samples from hand dug wells and boreholes were col- 
lected (Figure 1) in a container that was rinsed two to three times using the representative groundwater samples according to Barcelona et al. (1985). Water samples were filtered with UNICEF standard filter to free them from suspended particles. Samples were kept in a field cooler throughout the period of the sampling

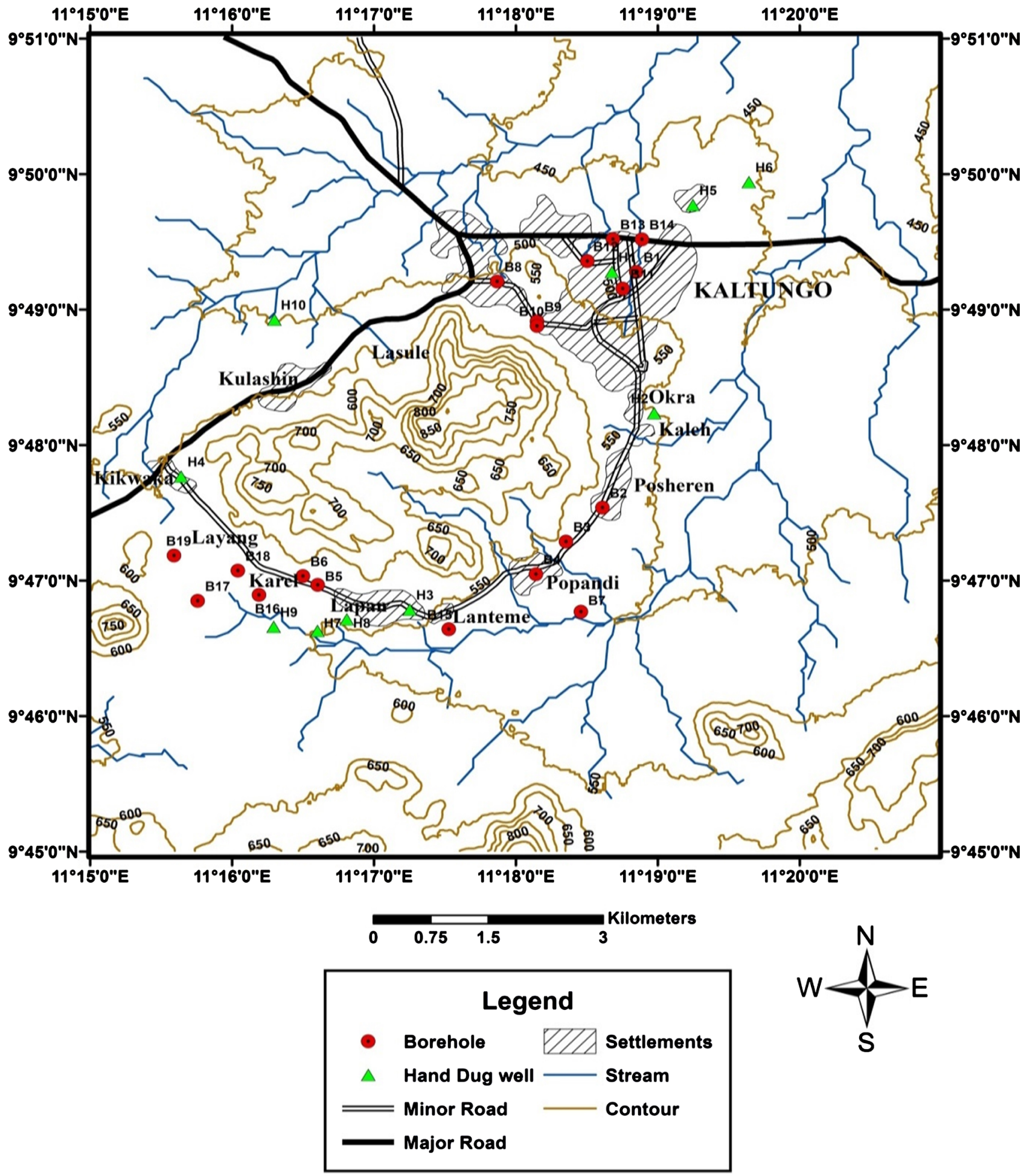

Figure 1. Topographical map of the study area showing water sample points. 

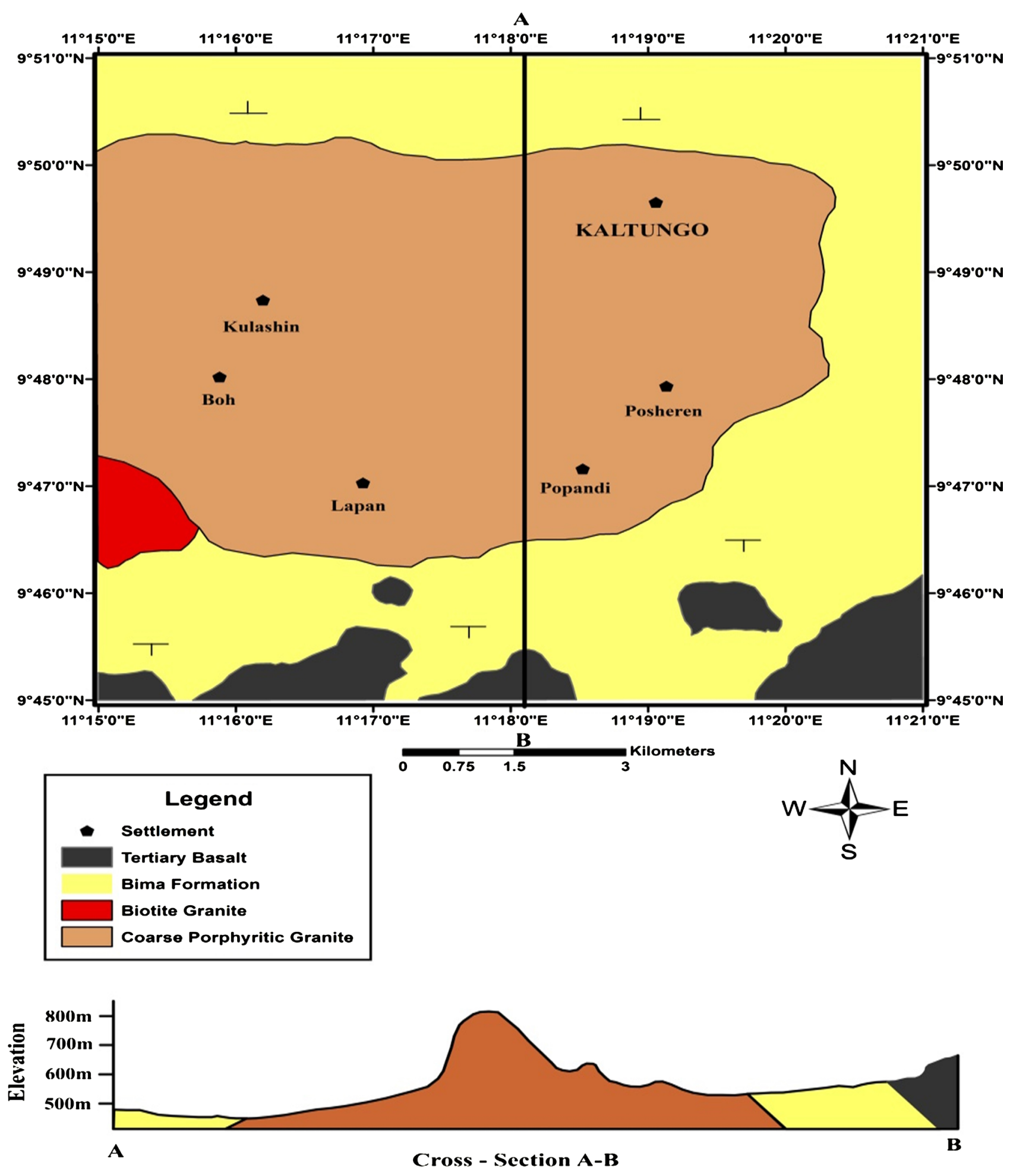

Figure 2. Geologic map of the study area.

exercise. The coordinates of each boreholes and hand-dug wells were determined using GPS (Model Garmine Trex HC Series), and later transferred to the base map of the study area. Immediately after sampling, field parameters such as: $\mathrm{pH}$ and Temperature were measured using Pen $\mathrm{PH}$ and Temperature meter 
(Model CT6021A), Turbidity was measured using Hand held turbidity meter (Model HAUX 2100Q), Conductivity was measured using Pen Conductivity meter (Model CT 3030), and Total Dissolved Solids (TDS) was measured using Pen TDS Meters (Model 21000). Carbonate and bicarbonate were determined in the field using titrimetric method by HACH Digital Titrator (Model 16900). All other parameters such as Potassium $\left(\mathrm{K}^{+}\right)$, Calcium $\left(\mathrm{Ca}^{2+}\right)$, Copper $\left(\mathrm{Cu}^{2+}\right)$, Sodium $\left(\mathrm{Na}^{+}\right)$, Magnesium $\left(\mathrm{Mg}^{2+}\right)$, Iron $\left(\mathrm{Fe}^{2+}\right)$, Manganese $\left(\mathrm{Mn}^{-}\right)$, Chloride $\left(\mathrm{Cl}^{-}\right)$, Nitrate $\left(\mathrm{NO}^{3-}\right)$, Fluoride $\left(\mathrm{F}\right.$, Zinc $(\mathrm{Zn})$, Sulphate $\left(\mathrm{SO}_{4}^{2-}\right)$, Lead $\left(\mathrm{Pb}^{-}\right)$and Chromium $\left(\mathrm{Cr}^{6+}\right)$ were determined in the laboratory by spectrophotometry using HACH digital Spectrophotometer (Model DR2400, USA).

The variables were subjected to Pearson correlation to observe the strength and direction of association that exist between fluoride and other parameters. The Karl Pearson correlation coefficient is used as a measure to establish the relationship between two variables $X$ and $Y$. The correlation studies are useful to find a predictable relationship which can be exploited in practice. It is used for the measurement of the strength and statistical significance of the relation between two or more water quality parameters. Direct correlation exists when increase or decrease in the value of one parameter is associated with a corresponding increase or decrease in the value of other parameter V.T Patil and P.R Patil (2011). To find the relationship between two parameters $x$ and $y$, the Karl Pearson's correlation coefficient, $r$ is used and it is determined as follows (Antony et al., 2008).

$$
r=\frac{n \sum X Y \sum X \sum Y}{\sqrt{\left[n \sum X^{2}-\left(\sum X\right)^{2}\right]\left[n \sum Y^{2}\right]-\left(\sum Y\right)^{2}}}
$$

Here, $n=$ number of data points; $x=$ values of $x$-variable; $y=$ values of $y$-variable. SPSS version 20 was used for the statistical analysis.

Characterisation of the water in the study area was done using Piper Trilinear Diagram. In the diagram, an ion can be considered as type facies when its concentration is within $50 \%$ to $100 \%$ domain. AqQa Software Version 1.5.0 was used to develop the piper diagram.

\section{Results and Discussion}

\subsection{Hydrogechemical Characteristics of Groundwater}

Table 1 shows the values of the physico-chemical results of groundwater from the study area. Temperature of the waters ranges from $24.6^{\circ} \mathrm{C}-29.70^{\circ} \mathrm{C}$ with a mean of $27.30^{\circ} \mathrm{C}$. Hydrogen exponent $(\mathrm{pH})$ ranges from $4.99-10.1$ with a mean of 7.23, indicating waters in the study area to be slightly acidic to mildly alkaline (Olasehinde et al., 2015). Total Dissolve Solids ranges from 64.99 - 211 with a mean of 120.75 indicating the water is fresh (Rao et al., 2010). Total Hardness ranges from 68.19 - 113.85 with a mean 88.36 , thus indicates moderately hard water (Rao et al., 2010). Calcium $\left(\mathrm{Ca}^{2+}\right)$ ranges from $34.88-61.03 \mathrm{mg} / \mathrm{l}$ with a mean of $47.42 \mathrm{mg} / \mathrm{l}$. Magnesium ranges from $30.09-59.83 \mathrm{mg} / \mathrm{l}$ with a mean of 
山 总

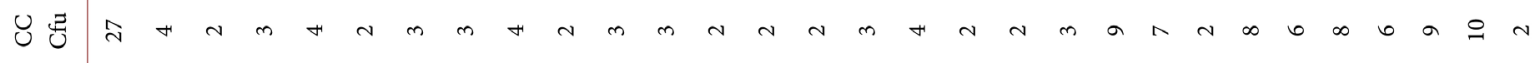

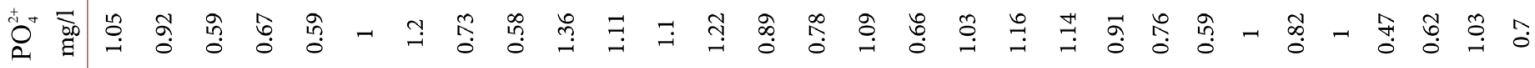

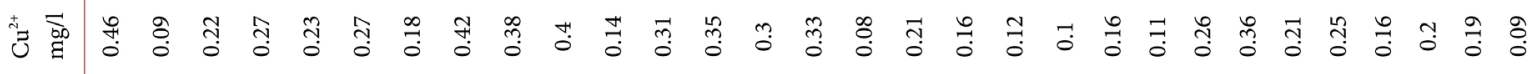

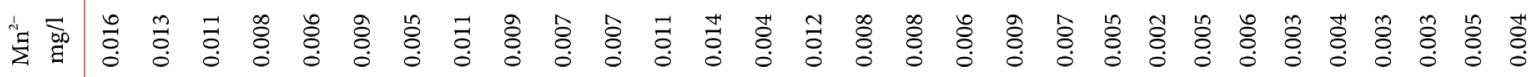
茫 总

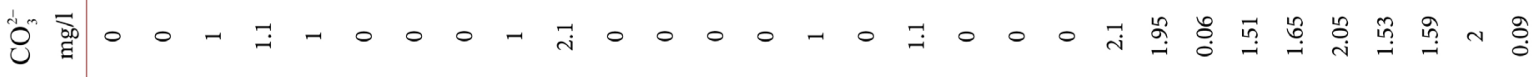

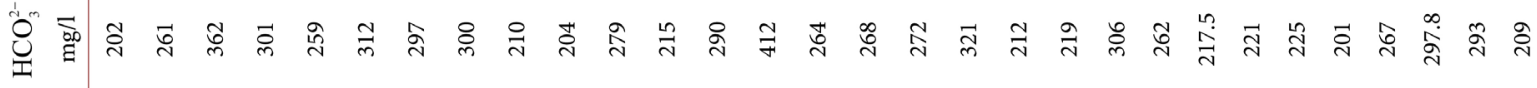

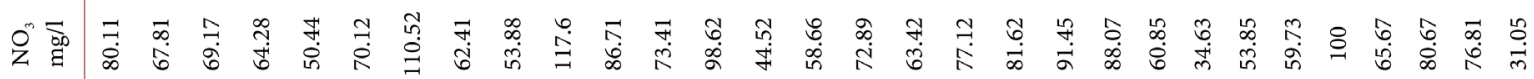

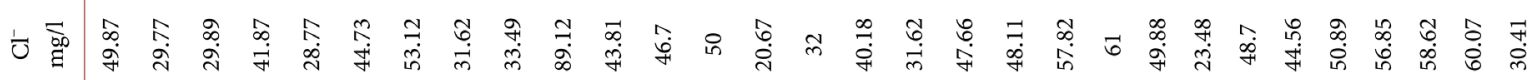

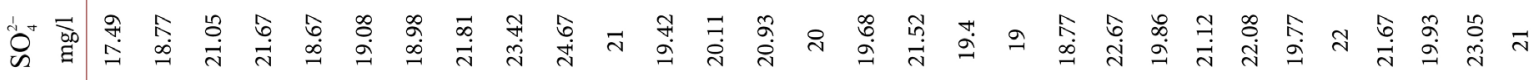

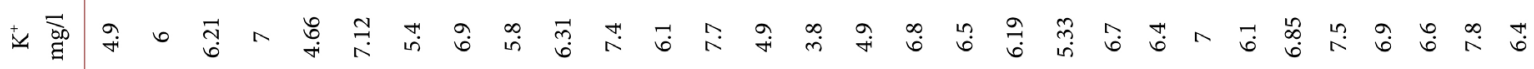

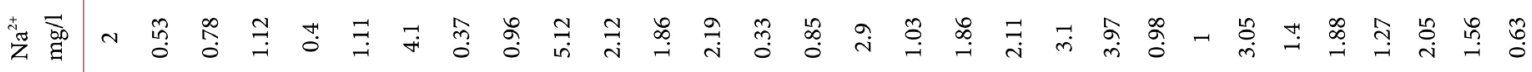

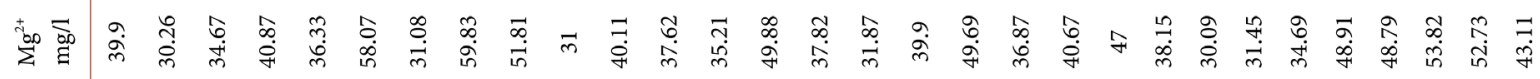

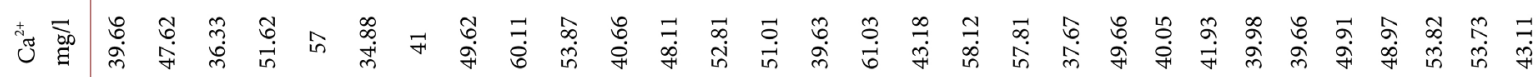

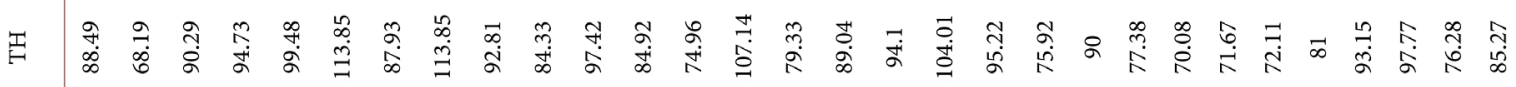

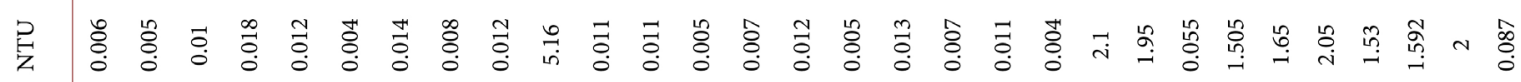

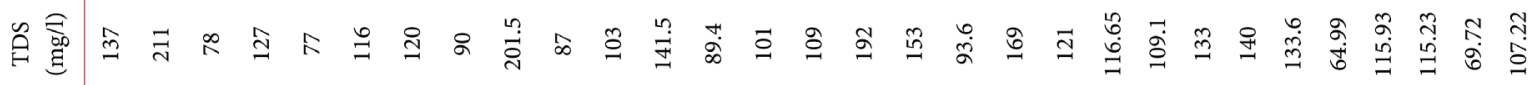

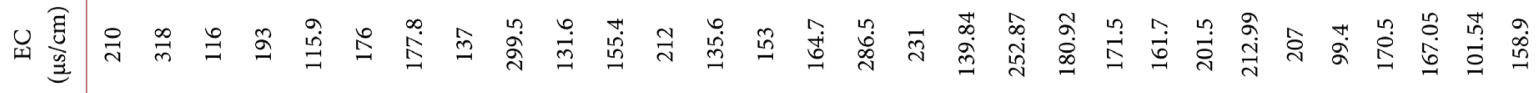

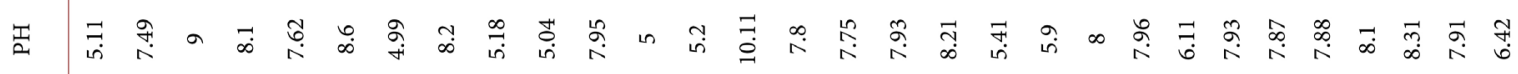

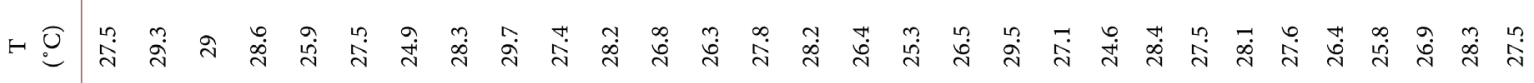

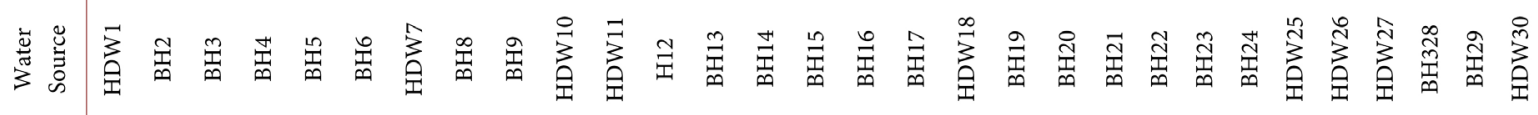

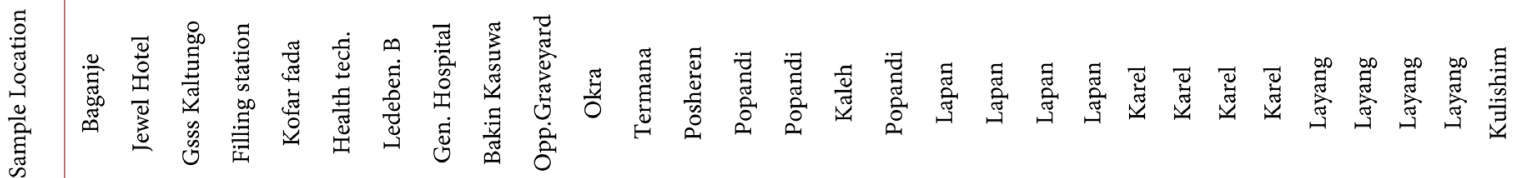

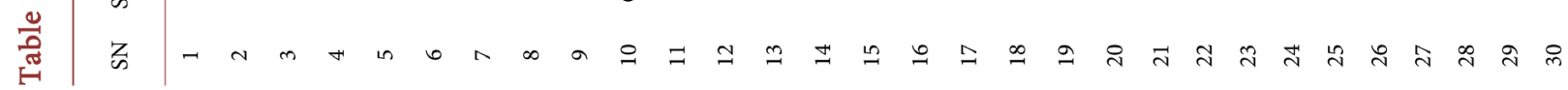


$41.40 \mathrm{mg} / \mathrm{l}$. Sodium ranges from 0.33 - 5.12 with a mean of $1.75 \mathrm{mg} / \mathrm{l}$. Potassium ranges from 3.8 - 7.8 with a mean of $6.27 \mathrm{mg} / \mathrm{l}$. Bicarbonate in the waters ranges from 201 - $412 \mathrm{mg} / \mathrm{l}$ with a mean of $265.31 \mathrm{mg} / \mathrm{l}$, sulfate ranges from 17.49 24.67 with a mean of $20.61 \mathrm{mg} / \mathrm{l}$. Chloride ranges from $20.67-89.12 \mathrm{mg} / \mathrm{l}$ with a mean of 44.51 . Fluoride ranges from $0.88-1.94 \mathrm{mg} / \mathrm{l}$ with a mean of $1.65 \mathrm{mg} / \mathrm{l}$. Nitrate ranges from 31.05 - $117.6 \mathrm{mg} / \mathrm{l}$ with a mean of $71.54 \mathrm{mg} / \mathrm{l}$. Iron ranges from $0.5-1.7 \mathrm{mg} / \mathrm{l}$ with a mean of $0.92 \mathrm{mg} / \mathrm{l}$. Majority of the water sources (ninety percent $90 \%$ ) have elevated levels of Fluoride and Iron with corresponding elevated levels of nitrate.

\subsection{Correlation Analysis}

The correlation coefficients $(r)$ among various water quality parameters have been calculated and the numerical values of correlation coefficients $(r)$ are tabulated in Table 2. Correlation coefficient $(r)$ between any two parameters, $x \& y$ is calculated for parameter such as T, pH, EC, TDS, TH, $\mathrm{HCO}^{3-}, \mathrm{Cl}^{-}, \mathrm{Na}^{+}, \mathrm{K}^{+}, \mathrm{Ca}^{2+}$, $\mathrm{Mg}^{2+}, \mathrm{NO}_{3}^{-}, \mathrm{SO}_{4}^{2-}, \mathrm{PO}_{4}^{-}, \mathrm{F}, \mathrm{Fe}^{2+}$, and $\mathrm{CC}$ of the ground water samples. The degree of line association between any two of the water quality parameters as measured by the simple correlation coefficient $(r)$ is presented as $17 \times 17$ correlation matrix. Poor correlation is observed between fluorides with nitrate; fluoride with sulfate and fluoride with chloride. This probably indicates that, the source of fluoride in the waters may not to be from anthropogenic sources, even though significant concentration of nitrate is present in over $90 \%$ of the water sources. Fluoride exhibits negative correlation with temperature, potassium and magnesium, while weak positive correlation is observed between fluoride and sodium, fluoride and calcium, fluoride and TDS, and fluoride and PH indicate dissolution of fluoride in the presence of these parameters. This is supported by positive correlation of $\mathrm{PH}$ and bicarbonate. Positive correlation between total hardness with magnesium and total hardness with bicarbonate with correlation coefficient values; $0.628,0.511$ revealed the contribution of these ions to temporary hardness of water in the area. However, Strong Positive correlation between EC and TDS, sodium and chloride, sodium and nitrate and chloride and nitrates with correlation coefficient values; $0.999,0.800,0.759$ and 0.766 shows the inputs of these ions to salinization of groundwater in the area. Weak Positive correlation between fluoride with calcium, sodium, EC and TDS indicates that these ions may be from the same source, possibly biotite. The source might be from bed rocks dissolution as indicated by moderate correlation of Fluoride and iron.

\subsection{Hydrogeochemical Facies}

Characterization of the water in the area using piper Trilinear diagram indicates that $\mathrm{Ca}+\mathrm{Mg}-\mathrm{HCO}_{3}$ water type constitute $74 \%$ of the water samples, $\mathrm{Ca}+\mathrm{Mg}-\mathrm{Cl}$ water type constitutes $26 \%$ of the waters (Figure 3 ). The $\mathrm{Ca}+\mathrm{Mg}-\mathrm{HCO}_{3}$ water type is the dominant water type which reflect compositions of waters of meteoric origin that resulted from the dissolution of aluminosilicate as a result 


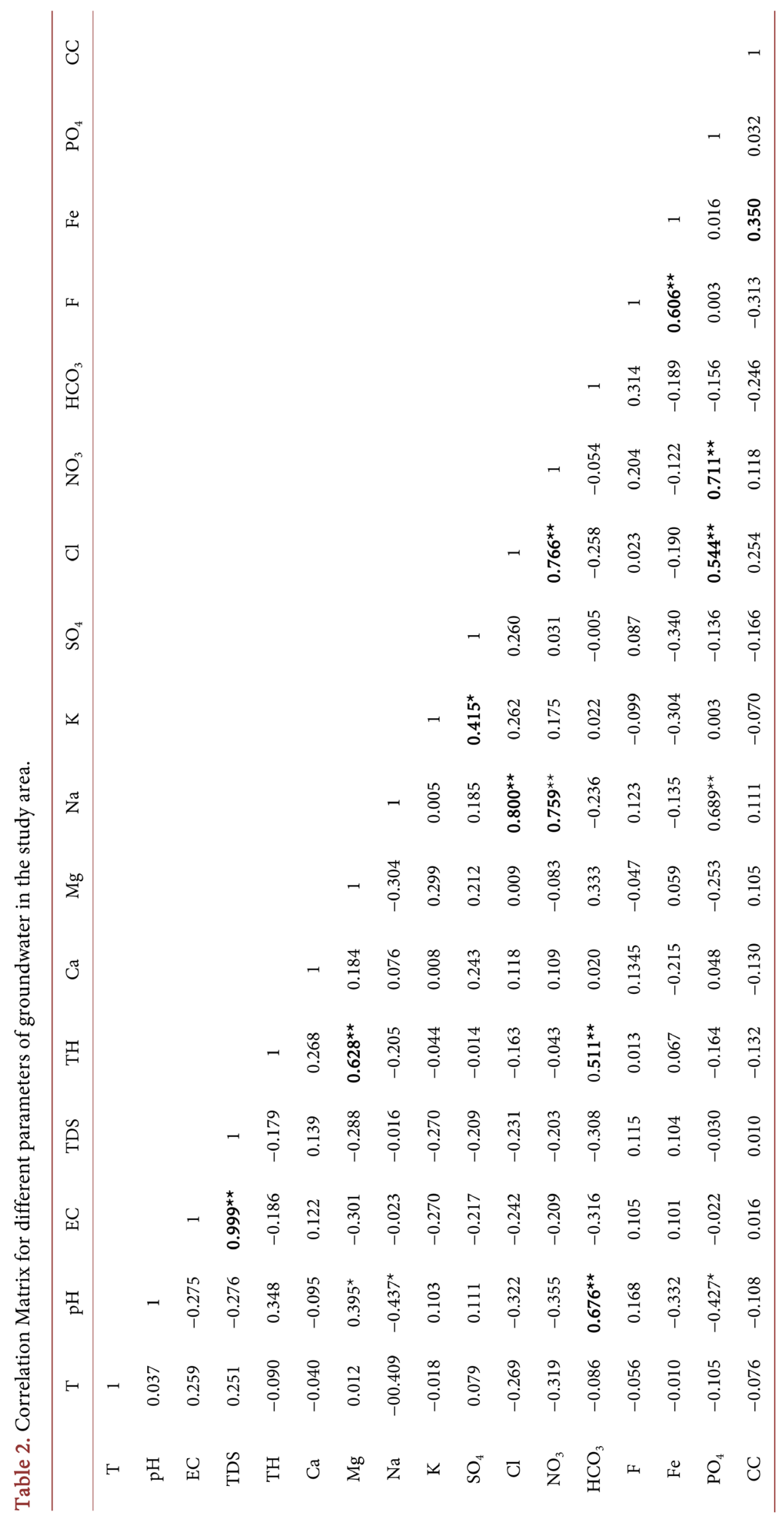




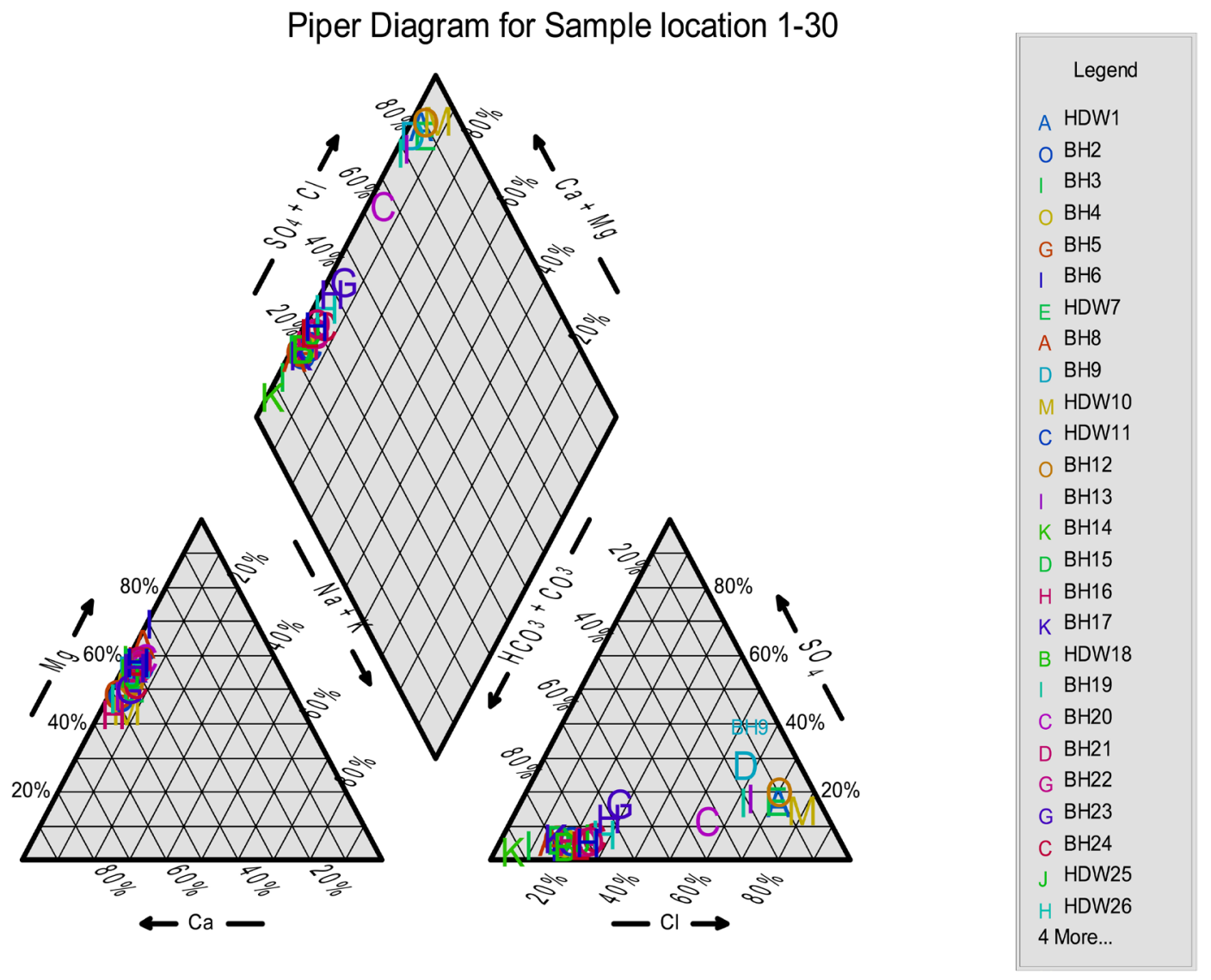

Figure 3. Diagram showing water types of the study area.

of induce chemical weathering. The $\mathrm{Ca}+\mathrm{Mg}-\mathrm{Cl}$ water type represent water of intermediate composition that evolved through simple hydrochemical mixing influenced by reverse cations exchange. This evolution was accomplished through the interaction of fossil groundwater of saline characteristics $(\mathrm{NaCl})$. The $\mathrm{NaCl}$ water interacted with $\mathrm{Ca}+\mathrm{Mg}-\mathrm{HCO}_{3}$ water at the recharge zone. $\mathrm{Ca}^{2+}$ and $\mathrm{Mg}^{2+}$ replace $\mathrm{Na}^{+}$in $\mathrm{NaCl}$ water type through reverse cations exchange leading to the formation of $\mathrm{Ca}+\mathrm{Mg}-\mathrm{Cl}$ water type.

\subsection{Spatial Distribution of Fluoride}

Fluoride distribution map of the study area is shown in Figure 4. The Map Shows that high Fluoride concentration are found around the central portion of the study area and towards the small portion of the south western part and also around the north eastern part (Figure 4). Low fluoride concentration is found occupying a small portion of the northwest and south east. No certain variation of fluoride concentration is observed in the different sources from which water was collected (Table 1). Waters collected from both the hand dug wells and boreholes (Table 1) have higher fluoride concentration. However, boreholes and hand dug wells have similar levels of fluoride, indicating that depths of water sources in the area do not determine concentration of fluoride. One of the water source (hand dug well at Ladeben B) located in the central portion of the study 


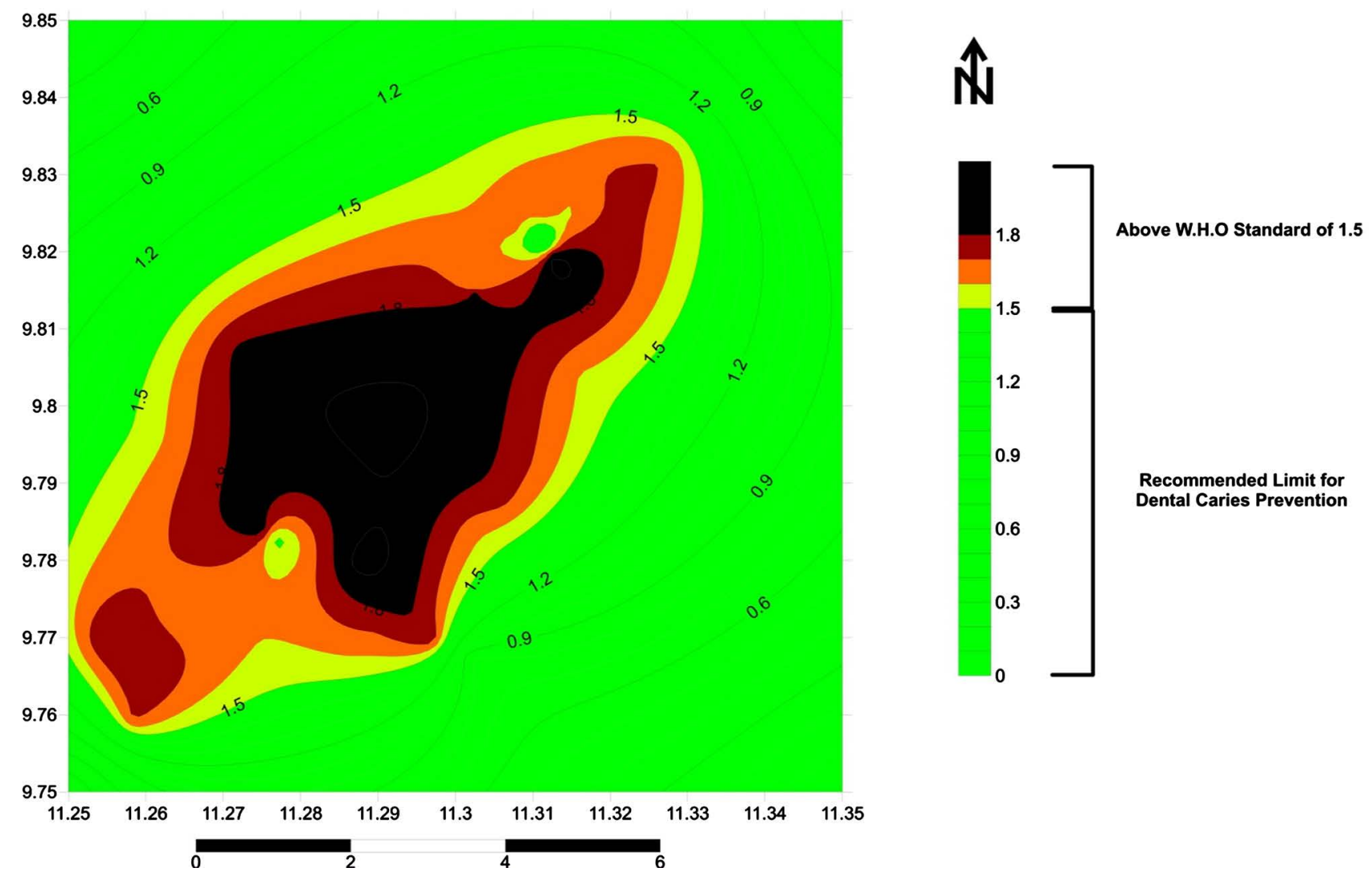

Figure 4. Fluoride distribution map of Kaltungo area.

area has the highest level of fluoride concentration of $1.94 \mathrm{mg} / \mathrm{l}$.

Out of the 30 water sources analysed for fluoride content, only 3 samples have fluoride within the WHO 2004 permissible limit of $0.5-1.5 \mathrm{mg} / \mathrm{l}$. Population of inhabitants consuming water from these sources may therefore be free from the risk of having dental caries. However, 27 samples of the water sources in the area have fluoride concentration greater than the $1.5 \mathrm{mg} / \mathrm{l}$ WHO upper limit. Based on the WHO (2004), classification of health effects of fluoride consumption in drinking water, population consuming water from 27 of the 30 water sources with fluoride value above $1.5 \mathrm{mg} / \mathrm{l}$ may likely have effect of dental fluorosis.

\section{Conclusion}

From the present study the relation between fluoride and various groundwater quality parameters has been derived by using correlation coefficient. The statistical data obtained in the present study indicate that the presence of fluoride in the water is as a result of dissolution of biotite within the host rock (Basalt). It is also observed that there are no clear variations of fluoride concentration recorded in hand dug wells and boreholes. Also, characterization of the water in the area using piper trilinear diagram indicates that all water types are associated with fluoride. And the fluoride concentration is higher towards the central portion of the study area. This study recommends that groundwater around the study area should be treated before consumption. 


\section{Conflicts of Interest}

The authors declare no conflicts of interest regarding the publication of this paper.

\section{References}

Abu Rukah, Y., \& Alsonkhny, K. (2004). Geochemical Assessment of Groundwater Contamination with Special Emphasis on Fluoride Concentration, North Jordan. Geochemistry, 64, 174-181. https://doi.org/10.1016/j.chemer.2003.11.003

Allix, P., Grosdidier, E., Jardiné, S., Legoux, O., \& Popoff, M. (1981). Découverte d'Aptien supérieur a Albian inférieur daté par microfossiles dans la série détritique cretacée du fossé de la Bénoué (Nigéria). Comptes Rendus Mathematique Academie des Sciences, Paris, 292, 1291-1294.

Antony, S. A., Balakrishnan, M., Gunasekaran, S., \& Natarajan, R. K. (2008). Impact of Dyeing Industrial Effluents on the Ground Water Quality in Kancheepuram (India). Indian Journal of Science and Technology, 1, 1-8.

Barcelona, M. J., Gibb, J. P., Helfrich, J. A., \& Garske, E. E. (1985). Practical Guide for Groundwater Sampling. ISWS Contract Report 374. Champaign, IL: Illinois State Water Survey Campaign.

Chidambaram, S., Bala Krishna Prasad, M., Manivannan, R., Karmegam, U., Singaraja, C., Anandhan, P., Prasanna, M. V., \& Manikandan, S. (2013). Environmental Hydrogeochemistry and Genesis of Fluoride in Groundwaters of Dindigul District, Tamilnadu (India). Environmental Earth Sciences, 68, 333-342.

https://doi.org/10.1007/s12665-012-1741-9

Deepu, T. R., \& Shaji, E. (2011). Fluoride Contamination in Groundwater Resources of Chittur Block, Palghat District, Kerala, India-Ahealth Risk. In Disaster, Risk and Vulnerability Conference 2011. School of Environmental Sciences, Mahatma Gandhi University, India in Association with the Applied Geoinformatics for Society and Environment, Germany, 12-14 March 2011.

Dibal, H. U., \& Schoeneich, K. (2009). Fluoride Concentration in the Groundwater of Northern Nigeria. Nigerian Association of Hydrogeologist. Conference Paper Page 22.

Dibal, H. U., Lekmang, I. C., \& Lar, U. A. (2008). Dental Fluorosis from Drinking Water Consumption in Langtang Town, Plateau State. Continental Journal of Earth Sciences, 3, 77-82.

Handa, B. K. (1975). Geochemistry and Genesis of Fluoride Containing Groundwater in India. Groundwater, 13, 275-281. https://doi.org/10.1111/j.1745-6584.1975.tb03086.x

Haruna, A. I., Usman, A. M., \& Abdullahi, A. M. (2014). Environmental Distribution of Fluoride in Drinking Waters of Kaltungo Area, North-Eastern Nigeria. American Journal of Environmental Protection, 3, 19-24.

Jacks, G., Bhattacharya, P., Chaudhary, V., \& Singh, K. P., (2004). Controls on the Genesis of Some High-Fluoride Groundwater in India. Applied Geochemistry, 20, 221-228. https://doi.org/10.1016/j.apgeochem.2004.07.002

Lar, U. A., \& Tejan, A. B. (2008). Highlights of Some Environmental Problems of Geomedical Significance in Nigeria. Environmental Geochemistry and Health, 30, 383-389. https://doi.org/10.1007/s10653-008-9161-1

Manikandan, S., Chidambaram, S., Ramanathan, A. L., Prasanna, M. V., Karmegam, U., Singaraja, C., Paramaguru, P., \& Jainab, I. (2014). A Study on the High Fluoride Concentration in the Magnesium-Rich Waters of Hard Rock Aquifer in Krishnagiri District, Tamilnadu, India. Arabian Journal of Geosciences, 7, 273-285. 
https://doi.org/10.1007/s12517-012-0752-X

Olasehinde, P. I., Amadi, A. N., Dan-Hassan, M. A., Jimoh, M. O., \& Okunlola, I. A. (2015) Statistical Assessment of Groundwater Quality in Ogbomosho, Southwest Nigeria. American Journal of Mining and Metallurgy, 3, 21-28.

Patil, V. T., \& Patil, P. R. (2011). Groundwater Quality of Open Wells and Tube Wells around Amalner Town of Jalgaon District, Maharashtra, India. Electronic Journal of Chemistry, 8, 53-78. https://doi.org/10.1155/2011/676213

Ramachandran, M., Chidambaram, S., Ulaganthan, K., Paluchamy, A., Sivaji, M., \& Hameed, S. (2012). Mapping of Fluoride Ions in Groundwater of Dindigul District, Tamilnadu, India-Using GIS Technique. Arabian Journal of Geosciences, 5, 433-439. https://doi.org/10.1007/s12517-010-0216-0

Ramesam, V., \& Rajagopalan, K. (1985). Fluoride Ingestion into the Natural Water of Hard Rock Areas, Peninsular India. Journal of the Geological Society of India, 26, 125-132.

Rao, Y. R. S., Keshari, A. K., \& Gosain, A. K. (2010). Evaluation of Regional Groundwater Quality Using PCA and Geostitistics in the Urban Coastal Aquifer, East Coast of India. International Journal of Environment and Waste Management, 5, 163-180. https://doi.org/10.1504/IJEWM.2010.029700

Reddy, D. V., Nagabhushanam, P., Sukhija, B. S., Reddy, A. G. S., \& Smedley, P. L. (2010). Fluoride Dynamics in the Granitic Aquifer of the Wailapally Watershed, Nalgonda District, India. Chemical Geology, 269, 278-289. https://doi.org/10.1016/j.chemgeo.2009.10.003

Shaji, E., Bindu Viju, J., \& Thambi, D. S. (2007). High Fluoride in Groundwater of Palghat District, Kerala. Current Science, 92, 240-245.

Srinivasamoorthy, K., Chidambaram, S., \& Vasanthavigar, M. (2008). Geochemistry of Fluorides in Salem District, Tamilnadu, India. Journal of Environmental Geology, 16, 25.

Srinivasamoorthy, K., Vijayaraghavan, K., Vasanthavigar, M., Subramanya, S., Chidambaram, S., Paluchamy, A., \& Manivannan, R. (2012). Assessment of Groundwater Quality with Special Emphasis on Fluoride Contamination in Crystalline Bed Rock Aquifers of Mettur Region, Tamilnadu, India. Arabian Journal of Geosciences, 5, 83-94. https://doi.org/10.1007/s12517-010-0162-x

WHO (2004). Guidelines for Drinking Water Quality (3rd ed.). Geneva: World Health Organization.

Zarboski, P. M., Ugodulunwa, F., Idornigie, A., Nnabo, P., \& Ibe, K. (1997). Stratigraphy and structure of the Cretaceous Gongola Basin, Northeastern Nigeria. Bulletin of Centre for Recherché Elf Exploration and Production, 21, 153-185. 